\title{
Ch. XV. Of Sampson, Eli, and Samvel
}

\section{Ch. XVI. Of Savl \\ Ch. XVII. Of David \\ Ch. XVIII. Of Salomon \\ Ch. XIX. Of Salomons Successors vntil the end of Iehosaphat}

\$3. Of the great battaile betweene Ieroboam and Abia, with a Corolarie of the examples of Gods iudgements.

Abijah the Sonne of Rehoboam, inherited his Fathers Kingdome, and his vices. He raised an Armie of foure hundred thousand, with which he inuaded Ieroboam, who encountred him with a double number of eight hundred thousand; both Armies ioyned neare to the Mount Ephraim, where Ieroboam was vtterly ouerthrowne, and the strength of Israel broken; for there fell of that side fiue hundred thousand, the greatest ouerthrow that euer was giuen or receiued of those Nations. Abijah being now master of the field, recouered Bethel, Ieshanah, and Ephron, soone after which discomfiture, Ieroboam died: who raigned in all 22. yeares. Abijah, the better to strengthen himselfe, entred into league with 